\title{
APPLICABILITY OF FINGERPRINTING FOR IDENTIFICATION OF SEDIMENT SOURCES IN A MESOSCALE SEMIARID CATCHMENT
}

\author{
Eveline M. R. da Silva ${ }^{*}$, Pedro Medeiros², José C. de Araújo ${ }^{3}$
}

${ }^{1 *}$ Corresponding author. Universidade Federal do Ceará/ UFC, Fortaleza - CE, Brasil. E-mail: evelinemenezessilva@ gmail.com

\section{KEYWORDS}

Sediment dynamics, soil physics, soil mineralogy, semiarid.

\begin{abstract}
The study aimed at identifying sediment sources in a mesoscale catchment $\left(933 \mathrm{~km}^{2}\right)$ located in the Brazilian semiarid region. The research explored the potential of using a fingerprinting technique to verify the origin of eroded sediments in a catchment by comparing physical and mineralogical properties of potential sediment sources and sediments deposited in a pond $\left(6 \times 10^{3} \mathrm{~m}^{3}\right.$ storage capacity) and a reservoir $\left(20 \times 10^{6} \mathrm{~m}^{3}\right.$ storage capacity). The goal was to assess the feasibility of using such material to identify sediment sources in a semiarid environment with a high density of surface reservoirs. Chemical variables were studied by mineralogical analysis using scanning electron microscopy (SEM) and multivariate statistics. The results showed that the fingerprinting technique is a potential tool to identify sediment sources comparing the properties of soils with silted material in reservoirs, allowing its use even in regions with low frequency of runoff.
\end{abstract}

\section{INTRODUCTION}

Agricultural and urban growth has increased river basin occupation, changing land uses and promoting high environmental and socio-economic impacts due to soil erosion. Erosion processes are natural but strongly intensified by anthropogenic actions, primarily caused by uncontrolled occupation and use of inappropriate farming practices (Santos et al., 2016). Hydro-sedimentological studies have great importance for environmental management since soil erosion intensifies land degradation and reduces agricultural production. In semiarid regions, erosive processes are of great importance because the large area of exposed soil due to the sparse xerophytic vegetation is easily reached by high intensities of rainfall (Santos et al., 2017).

Additionally, society is affected by transport and deposition of eroded sediments, for instance by reducing the storage capacity of surface reservoirs (Medeiros et al., 2014). Sediment deposition can also degrade water quality, increasing concentration of suspended solids and decreasing incidence of solar radiation, which could reduce dissolved oxygen contents. In the Northeast of Brazil, where nearly $90 \%$ of the water used for human supply is stored in such structures, the impact on water availability is significant (Araújo et al., 2006). Furthermore, sediment retention in reservoir network impacts its dynamics at a catchment scale, reducing connectivity and limiting sediment transference from hillslopes to the outlet, as discussed by Medeiros et al. (2014).

In semiarid regions, the great challenge for monitoring sediment yield lies in the limited times of natural flow events, making it difficult to analyze hydrosedimentological responses to these events (Figueiredo et al., 2016). Nonetheless, river basin monitoring programs must be implemented for the purpose of evaluating hydrology, water quality, and sediment yield. The quantity and quality of sediments reaching rivers, besides informing about the state of a catchment area, are relevant to the maintenance of ecosystems, what could aid in planning the use of water resources of a region (Bronstert et al., 2014).

Collins \& Walling (2002) showed that, since the beginning of the 2000s, considerable attention has been focused on developing methods to identify sediment sources. The detachment and transport of soil particles (from various sources) occur throughout catchments, and sediments are propagated in suspension and/or dragged through a drainage network. The extent to which each of these sources contributes varies with time and space.

One of the most promising methods to identify the origin of sediments, which have been highlighted by its efficiency, is fingerprinting (Collins et al., 1997; Collins \& Walling, 2002; Walling, 2013; Brosinsky et al., 2014). This technique is based on the principle that sediments

${ }^{2}$ Instituto Federal de Educação, Ciência e Tecnologia do Ceará/ IFCE, Ceará, Brasil

${ }^{3}$ Universidade Federal do Ceará/ UFC, Fortaleza - CE, Brasil.

Received in: 6-1-2017

Accepted in: 4-26-2018 
maintain part of their geochemical and mineralogical properties, originally acquired at sources; therefore, these properties can be used as tracers. The knowledge on sediment sources promotes a better understanding of water and sediment flows, allowing sustainable management of catchment areas.

This research explored the potential of using a fingerprinting technique to verify the origin of eroded sediments in a mesoscale semiarid catchment, with a high density of surface reservoirs (about 1 reservoir per $8 \mathrm{~km}^{2}$ ). This was assessed by means of comparing the physical and mineralogical properties of potential sources nearby and of silted sediments found in a pond (formed by the damming outlet) and in a surface reservoir.

\section{MATERIAL AND METHODS \\ Study area}

The study was conducted in the Benguê catchment, located in the semiarid Northeast region of Brazil, which has an area of $933 \mathrm{~km}^{3}$. Within this, two sections were studied: the Benguê reservoir $\left(20 \times 10^{6} \mathrm{~m}^{3}\right.$ storage capacity) at the catchment outlet; and the Aroeira section, located upstream the reservoir, with an area of $800 \mathrm{~km}^{2}$ (Figure 1), where a weir over the road formed a pond $(6 \mathrm{x}$ $10^{3} \mathrm{~m}^{3}$ storage capacity). There are 121 surface reservoirs in the Benguê catchment, resulting in a density of one reservoir per $7.7 \mathrm{~km}^{2}$, on average.

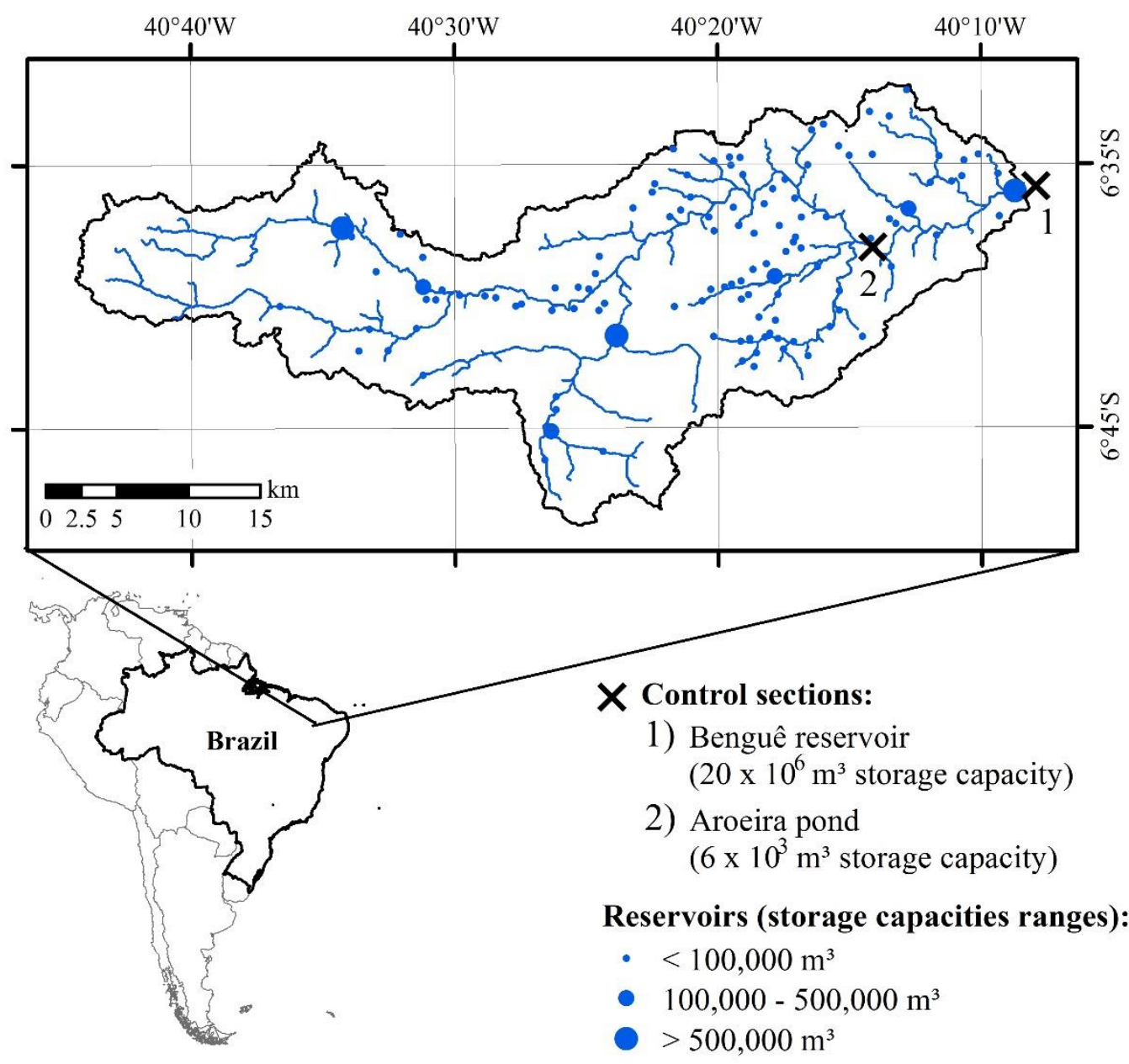

FIGURE 1. Location map of the Benguê catchment in the northeast of Brazil.

The catchment is located in one of the driest regions of the country (Figueiredo et al., 2016). The climate is semiarid tropical with an average annual rainfall of $550 \mathrm{~mm}$ and annual potential evaporation of about $2,500 \mathrm{~mm}$. The area has a well-defined rainy season, from January to May, which accounts for more than $80 \%$ of the annual rainfall, of which $46 \%$ during March and April. Rains are convective of high intensity and short duration. The rainfall regime is characterized by high interannual variability, with a coefficient of variation of 0.40 for annual precipitation and 1.20 for annual runoff (Medeiros \& Araújo, 2014).

Regarding geomorphological aspects, the catchment is located in a transition zone with occurrence of Sertões units (hinterlands) in the central and eastern portions, and Altos Planaltos Sedimentares (high sedimentary plateaus) to the south and west edges. Sertões units are characterized by shallow soils on crystalline bedrocks, with high clay content and a large amount of rock fragments. For Medeiros et al. (2010), these characteristics are responsible for defining runoff patterns, with higher runoff coefficients in hinterlands and high infiltration in sedimentary plateaus.

According to RadamBrasil (1981), the local soils are classified as:

- Luvisols: shallow, with well-differentiated profiles, and associated with surface stoniness (desert soils);

- Latosols: well-developed, usually deep, well-drained, friable, and porous; 
- Planosols: relatively shallow, poorly drainage, unstructured in rainy periods and cracked in dry seasons;

- Argisols: well-developed and drained, with clayey texture, and located in the lower and flatter parts of relief. They are usually stony or covered by numerous pebbles;

- Neosols: shallow, generally stony, and of varying texture and fertility, which depends on the source material. They are found in gently undulating and steep terrains, and usually associated with rocky outcrops.

Such soil heterogeneity has a strong influence on erosion processes and sediment deposition in the catchment. According to Medeiros et al. (2010), deposition of eroded sediments is common in areas of deep soils and high infiltration rates, even after high-magnitude rainfalls. Conversely, shallow soils on crystalline bedrocks provide high sediment connectivity.

\section{Sampling procedure}

Soil and sediment samples were collected from potential source locations, pond, and Benguê reservoir in May and September 2014, following procedures previously adopted in other studies, as presented by Walling (2013).

Walling \& Collins (2000) stated that potential sediment sources are usually associated with different land uses and/or soil types, and the characteristics that prevail are the most heterogeneous within the catchment, as discussed by Brosinsky et al. (2014). In this study, potential sources included the various soil patches, where each soil type corresponded to one source. This was because of the high soil heterogeneity in the area, while land use was rather homogeneous (Medeiros et al., 2010). Therefore, in this case, the soil properties prevailed over land use. Some minor hotspots, such as unpaved roads, have been pointed as potential sediment sources in other studies., Minella et al., 2009); however, they were disregarded in this study due to the low population density in the catchment (roughly 7 inhabitants per $\mathrm{km}^{2}$ ), which reduces the number of roads as well.

Soil samples were collected using a cutting shovel to dig small trenches in the upper soil layer $(0.00-0.05$ $\mathrm{m})$, where erosion is more intense. Figure 2 illustrates the soil sampling sites; and Table 1 presents the area occupied by each soil type and the respective number of samples collected, which varied with soil representativeness and access conditions. Each soil sample was composed of five sub-samples, insofar as the following characteristics are obeyed: soil-type representativeness, slope position, vegetation cover homogeneity, soil color, and texture. The sub-samples were mixed to obtain a representative sample, totaling about $1 \mathrm{~kg}$. The procedure adopted for soil sampling was the same as that proposed by Minella et al. (2009)

TABLE 1. Soil-type representativeness and number of samples collected.

\begin{tabular}{cccc}
\hline Soil type & Area $\left(\mathbf{k m}^{\mathbf{2}}\right)$ & Area (\%) & Samples \\
\hline Luvisols & 138.2 & 14.8 & 10 \\
Latosols & 274.9 & 29.5 & 6 \\
Planosols & 283.1 & 30.3 & 4 \\
Argisols & 96.2 & 10.3 & 5 \\
Neosols - dystrophic & 74.1 & 7.9 & 4 \\
Neosols - eutrophic & 66.5 & 7.1 & 4 \\
\hline Total & $\mathbf{9 3 3}$ & $\mathbf{1 0 0}$ & $\mathbf{3 3}$ \\
\hline
\end{tabular}

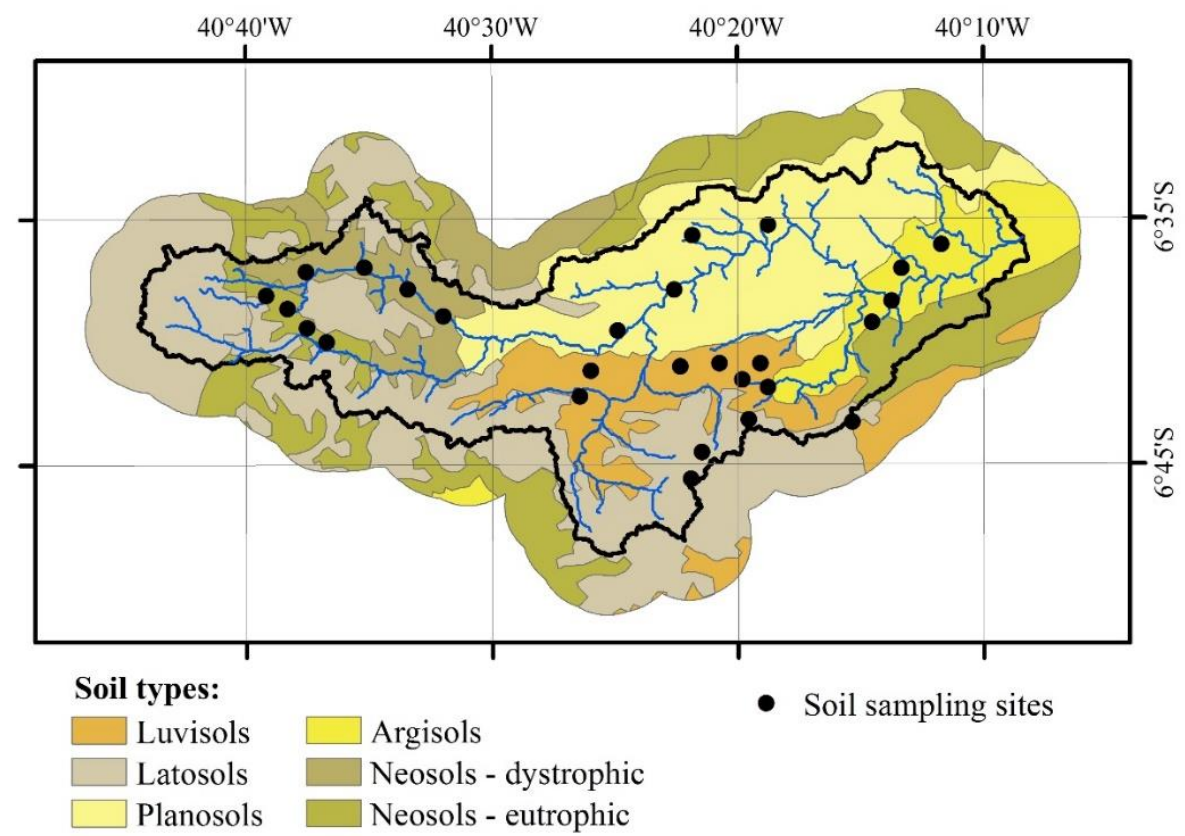

FIGURE 2. Soil sampling sites in the Benguê catchment. 
According to Walling (2013), sediment sampling is a key factor in sediment source fingerprinting investigations, as the sampled material must be representative of sediment export from a catchment, including its variability among different seasons and after rainfalls of different magnitudes. The author stated that such representativeness can be achieved by collecting suspended sediments by time-integrating samplers or directly from deposited sediments in floodplains or deposition zones in the channel bed/reservoirs.

The study region is located in a semiarid environment with ephemeral rivers, low rainfall (around 15 events with more than $10 \mathrm{~mm}$ per year) and flow (5 events per year, in first-order streams), as shown by Figueiredo et al. (2016). Based on this, we decided to sample sediments directly from deposition zones, specifically from the pond and Benguê reservoir.

The technique consisted of collecting composite sediment samples from the upper soil layer $(0.00-0.05$ $\mathrm{m})$, composed of five sub-samples spatially distributed. The number of composite samples was four from the Benguê reservoir, six from the pond, and four from pond banks (out of the river networks). The latter were sampled to verify whether sediments from banks differ from those from pond bed, in addition to identifying whether the silted material was formed only by erosion processes on the banks or originated from the entire catchment.

\section{Mineralogical and physical characterization}

All the soil and sediment samples were analyzed jointly, being air-dried and ground prior to the laboratory procedures.

The mineralogical analyses were carried out by scanning electron microscopy (SEM). A small portion of each sample was deposited on a double-sided carbon tape affixed to a stub. The carbon tape was to improve soil/sediment conductivity, so they had to undergo a metallization process. Additionally, deposited layers can improve electron emission, which enhances imaging. Afterward, the samples were submitted to SEM analysis, through which the emitted electrons affect the sample to produce a spectrum that provides information on its chemical composition.

By this technique, 21 elements can be identified (aluminum, barium, calcium, cerium, chromium, iron, iridium, lanthanum, magnesium, manganese, neodymium, nickel, potassium, phosphorus, silicon, silver, sodium, sulfur, titanium, ytterbium, and zirconium). After the analysis, the data were submitted to the Kruskal-Wallis test to determine which one had a discriminating capacity.

For physical characterization, standard methods (sieving and sedimentation) were used to determine the size of primary particles (EMBRAPA, 1997).

If only suspended sediments are used to identify the sources, two measures can be used to correct the effect caused by the fine-enrichment process on sediment transport: i) establish a maximum mean diameter for sediment particles transported in suspension or; (ii) adopt a correction factor based on a sample chemical concentration proportional to the percentage of the grain size of interest (Walling \& Collins, 2000). But, in this study, no correction was applied since silted sediment was used, which comprehends all the grain size fractions of material transported throughout the catchment to the outlet.

\section{Discrimination of sediment sources}

The first step to identify sediment sources was comparing samples from the different soil types to test significant differences between sources and identify elements able to separate them. Data analysis was conducted with the non-parametric test of Kruskal-Wallis or H-test (Walling \& Collins, 2000), testing a null hypothesis in which $\mathrm{k}$ independent random samples originate from the same population (Equation 1).

$$
H=\frac{12}{n(n+1)} \sum_{s=1}^{k} \frac{R_{s}}{n_{1}}-3(n+1)
$$

Where,

$\mathrm{R}_{\mathrm{s}}$ refers to the sum of positions at which each source sample $s$ assumes when all samples are placed in an ascending order (series);

$\mathrm{n}_{1}$ is the number of observations of source $s$;

$\mathrm{n}$ is the sum of $\mathrm{n}_{1}$, and

$\mathrm{k}$ is the number of sources.

The Kruskal-Wallis test was used to verify which elements had a discriminant capacity for the potential sediment sources, in addition to investigating whether the material from the pond banks had any element able to differentiate it from the silted sediment from inside the pond. Walling \& Woodward (1995) pointed out that the set of properties chosen must reflect the different controls and behaviors of sediment yield process, so as to maximize the degree of discrimination.

Once the discriminant elements were defined, the percentage contribution of each sediment source to the silted sediment in the pond and Benguê reservoir was calculated. Minella et al. (2009) stated that each source contribution can be estimated by comparing the set of tracer variables from sources and from sediments and then finding the best proportion of each source to reproduce the concentration of chemical elements in sediment samples. This condition is reached through a multivariate classification analysis and minimization function for the solution of overdetermined systems.

Equation 2 (Collins et al., 1997) was also adopted to describe the numerical relationship between the chemical composition of outlet sediments and the sources, as well as their proportions.

$$
y_{i}=\sum_{s=1}^{n} C_{s i} P_{s}
$$

Where,

$\mathrm{y}_{\mathrm{i}}$ is the concentration of chemical element $i(i=1$, $2,3, \ldots, \mathrm{m})$ in sediments;

$\mathrm{C}_{\mathrm{si}}$ is the concentration of chemical element $i$ in source $s(\mathrm{~s}=1,2, \ldots \mathrm{g})$,

Ps is the proportion to which a source $s$ contributes to the sediment. 
Walling \& Woodward (1995) proposed an objective function to calculate the contribution of each source (Ps) by minimizing the sum of squares of residues (Equation 3 ). The objective function is conditioned by two constraints:

I. Each source contribution must be a non-negative value (Equation 4);

II. The sum of the contributions of all sources equals 1 (Equation 5).

$$
\begin{aligned}
& f=\sum_{i=1}^{m}\left\{\left(C_{i}-\left(\sum_{s=1}^{n} C_{s i} P_{s}\right)\right) / C_{i}\right\}^{2} \\
& 0 \leq P_{s} \leq 1 \\
& \sum_{s=1}^{n} P_{s}=1
\end{aligned}
$$

Where

$\mathrm{C}_{\mathrm{i}}$ is the concentration of tracer variable $i$ in a sediment sample.

\section{RESULTS AND DISCUSSION}

\section{Physical characterization}

Grain size characterization of both soil and sediment samples aimed at comparing material in the origin and catchment outlet since grain size is directly related to important attributes of sediment quality (Poleto et al., 2009) that are used as trace elements. Figure 3 presents the grain size distribution for each soil type and for sediments from Aroeira pond and Benguê reservoir.

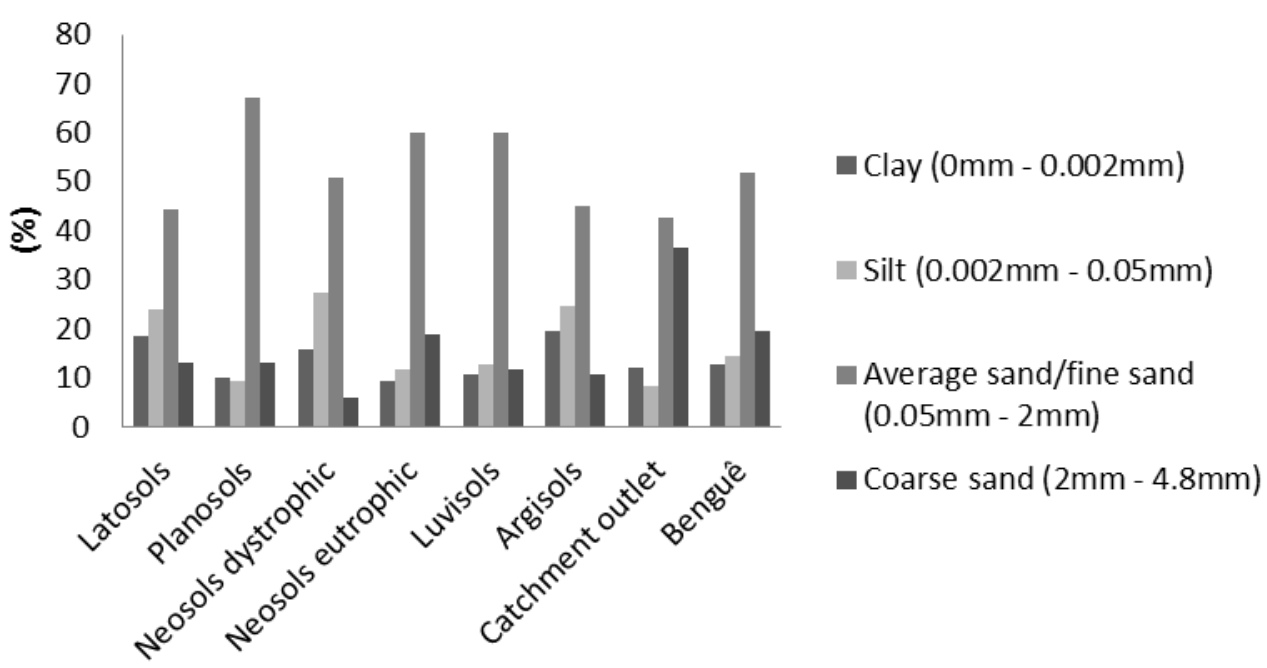

FIGURE 3. Grain size distribution for soil and sediment samples.

Figure 3 demonstrates that sediments from the reservoir have a higher content of fine material (clay and silt) than do those in the pond, where a coarse sand fraction is significant. This is due to the low water accumulation capacity in the pond, allowing spilling when flow increases in the stream, and hence the transport of fine sediments to the Benguê reservoir at the catchment outlet.

In contrast, the Benguê reservoir has a very low outflow rate, and has reached its maximum capacity only twice in the last 15 years; this has enabled retention of a large amount of sediment produced in the catchment area, of all grain sizes.

The results achieved using fingerprinting technique are in accordance with those presented by Medeiros et al. (2014), who described the effect of a surface-reservoir network on sediment flows based on physicalmathematical modeling. The authors argued that sediments eroded from headwaters are retained in reservoirs with low outflow frequency, thus acting as effective barriers against sediment propagation. When a high hydrological connectivity is achieved, after years of significant rainfalls, sediments are transported along the catchment through the reservoir network, and hence reaching the outlet.

\section{Comparison of sediments from the pond bed and soil from pond banks}

Initially, sediment samples from the pond bed were compared to soil samples from the banks to verify whether the material comes from the banks or from soils along the catchment. At this stage, a mineralogical analysis was performed and identified 20 elements in the samples, as shown in Table 2. Through Kruskal-Wallis test, eight of these elements presented a discriminant capacity (Ag, Al, $\mathrm{Ba}, \mathrm{Cr}, \mathrm{Mg}, \mathrm{Na}, \mathrm{Ni}$, and $\mathrm{Y}$ ), thus sediments from pond bed could be used to identify sediment sources in the catchment. 
TABLE 2. Results of the Kruskal-Wallis test to identify sediment sources in the pond bed.

\begin{tabular}{cccc}
\hline Variable & H value & H limit value & p \\
\hline $\mathrm{Ag}$ & 6.54 & 3.84 & $95 \%$ \\
$\mathrm{Al}$ & 2.91 & 2.71 & $90 \%$ \\
$\mathrm{Ba}$ & 6.54 & 3.84 & $95 \%$ \\
$\mathrm{C}$ & 0.41 & 6.63 & $99 \%$ \\
$\mathrm{Ce}$ & 0.18 & 6.63 & $99 \%$ \\
$\mathrm{Cr}$ & 6.54 & 3.84 & $95 \%$ \\
$\mathrm{Fe}$ & 0.18 & 6.63 & $99 \%$ \\
$\mathrm{Ir}$ & 2.27 & 6.63 & $99 \%$ \\
$\mathrm{~K}$ & 0.18 & 6.63 & $99 \%$ \\
$\mathrm{La}$ & 0.04 & 6.63 & $99 \%$ \\
$\mathrm{Mg}$ & 2.91 & 2.71 & $95 \%$ \\
$\mathrm{Mn}$ & 0.73 & 6.63 & $99 \%$ \\
$\mathrm{Na}$ & 6.54 & 3.84 & $95 \%$ \\
$\mathrm{Nd}$ & 0.18 & 6.63 & $99 \%$ \\
$\mathrm{Ni}$ & 6.54 & 3.84 & $95 \%$ \\
$\mathrm{P}$ & 0.18 & 6.63 & $99 \%$ \\
$\mathrm{Si}$ & 0.18 & 6.63 & $99 \%$ \\
$\mathrm{Ti}$ & 0.18 & 6.63 & $99 \%$ \\
$\mathrm{Y}$ & 2.90 & 2.71 & $90 \%$ \\
$\mathrm{Zr}$ & 2.23 & 3.84 & $95 \%$ \\
\hline
\end{tabular}

$\mathrm{H}$ - value of the discrimination test approaching the values of the chi-square distribution;

$\mathrm{p}$ - probability of sources being different from one another, according to the chi-square distribution.

Discriminant elements for sediment sources and pond/reservoir

The six soil types identified in the Benguê catchment (Latosols, Planosols, dystrophic Neosols, eutrophic Neosols, Luvisols, and Argisols) were considered possible sources of sediment, where 22 elements were identified through mineralogical analyses (Table 3). Despite differences in size, soil types, and sampling procedures, most of the elements identified in the Benguê catchment have already been found in other studies. For instance, Collins et al. (2010) tested 24 variables (Al, Ba, Bi, Dy, Fe, Ga, Gd, Ho, K, Mo, Na, Nd, $\mathrm{Pb}, \mathrm{Pd}, \mathrm{Sm}, \mathrm{Sn}, \mathrm{Sr}, \mathrm{Tb}, \mathrm{Ti}, \mathrm{Y}, \mathrm{Yb}$, and $\mathrm{Zn}$ ) in southwestern
$\mathrm{UK}$, of which eight (Al, Ba, Fe, K, Na, Nd, Ti, and Y) were also identified in the present study. Minella et al. (2009) identified ten elements (Al, C, Ca, Cr, Fe, Mn, N, $\mathrm{Na}, \mathrm{P}$, and $\mathrm{Zn}$ ) in a small rural catchment in southern Brazil, of which eight ( $\mathrm{Al}, \mathrm{C}, \mathrm{Ca}, \mathrm{Cr}, \mathrm{Fe}, \mathrm{Mn}, \mathrm{Na}$, and $\mathrm{P}$ ) were also present in the Benguê catchment.

The elements $\mathrm{Al}, \mathrm{Ce}, \mathrm{Fe}, \mathrm{La}, \mathrm{Mg}, \mathrm{Nd}$, and $\mathrm{Si}$ were present in all possible sources of sediments at varying concentrations. The Cr was detected only in Latosols, and $\mathrm{Cu}$ in Planosols. The $\mathrm{Y}$, a chemical element considered rare and present in lunar rocks and meteorites, was identified in two soil types of the Benguê catchment (Latosols and Luvisols). 
TABLE 3. Mean concentrations of the chemical elements analyzed in the sediment sources.

\begin{tabular}{|c|c|c|c|c|c|c|}
\hline \multirow[b]{2}{*}{ Element } & \multicolumn{6}{|c|}{ Sediment source } \\
\hline & Argisols & Latosols & Luvisols & $\begin{array}{c}\text { Neosols - } \\
\text { dystrophic }\end{array}$ & $\begin{array}{l}\text { Neosols - } \\
\text { eutrophic }\end{array}$ & Planosols \\
\hline $\mathrm{Ag}$ & $\mathrm{Nd}$ & 0.31 & $\mathrm{Nd}$ & 0.11 & nd & nd \\
\hline $\mathrm{Al}$ & 9.47 & 10.75 & 8.38 & 7.38 & 8.45 & 9.51 \\
\hline $\mathrm{Ba}$ & 3.75 & nd & nd & 1.25 & 2.16 & nd \\
\hline $\mathrm{C}$ & 0.58 & 1.45 & 4.21 & nd & 0.72 & nd \\
\hline $\mathrm{Ca}$ & 0.22 & 0.11 & 0.19 & nd & 0.04 & nd \\
\hline $\mathrm{Ce}$ & 1.50 & 3.09 & 2.30 & 3.04 & 3.40 & 5.99 \\
\hline $\mathrm{Cr}$ & nd & 1.00 & nd & nd & nd & nd \\
\hline $\mathrm{Cu}$ & nd & nd & nd & nd & nd & 0.7 \\
\hline $\mathrm{Fe}$ & 19.48 & 22.36 & 12.86 & 15.00 & 14.91 & 13.44 \\
\hline $\mathrm{Ir}$ & nd & 1.08 & 0.65 & nd & nd & nd \\
\hline $\mathrm{K}$ & nd & 0.57 & nd & 0.46 & nd & 0.92 \\
\hline $\mathrm{La}$ & 1.2 & 1.4 & 0.55 & 1.25 & 1.79 & 3.01 \\
\hline $\mathrm{Mg}$ & 0.28 & 0.4 & nd & 0.13 & 0.09 & 0.36 \\
\hline $\mathrm{Mn}$ & 0.26 & 0.18 & 0.39 & nd & 0.21 & 0.44 \\
\hline $\mathrm{Na}$ & nd & nd & 0.31 & 0.08 & nd & 0.08 \\
\hline $\mathrm{Nd}$ & 1.00 & 1.39 & 0.88 & 0.76 & 1.13 & 1.98 \\
\hline $\mathrm{Ni}$ & nd & 0.32 & 0.89 & nd & nd & 0.37 \\
\hline $\mathrm{P}$ & 2.52 & 3.34 & nd & 3.06 & 4.20 & 5.54 \\
\hline $\mathrm{S}$ & 1.94 & nd & 0.38 & 0.63 & 1.20 & nd \\
\hline $\mathrm{Si}$ & 28.31 & 25.82 & 31.75 & 34.39 & 30.96 & 31.18 \\
\hline $\mathrm{Ti}$ & 5.65 & 15.66 & 10.32 & nd & 6.35 & 11.15 \\
\hline $\mathrm{Y}$ & nd & 0.65 & 0.34 & nd & nd & nd \\
\hline $\mathrm{Zr}$ & 16.80 & 11.26 & nd & 23.04 & 16.04 & 13.61 \\
\hline
\end{tabular}

nd - not detected

The significance level of the Kruskal-Wallis test ranged from 1 to 5\%, i.e. 5 degrees of freedom, from which 9 elements were selected (C, Ca, Cr, Cu, Ir, Na, Ni, S, Y, and Zr). The statistical procedure proposed by Collins et al. (1997) was used to confirm element potential for source discrimination. Table 4 shows the results of the use of fingerprinting technique to discriminate sediment sources. According to Collins et al. (2010), the test selects variables and eliminates those of redundant properties.

TABLE 4. Elements with discriminant capacity for sediment sources selected by Kruskal-Wallis test

\begin{tabular}{cccc}
\hline Variable & H value & H limit value & P \\
\hline $\mathrm{C}$ & 15.98 & 6.63 & $99 \%$ \\
$\mathrm{Ca}$ & 12.92 & 3.84 & $95 \%$ \\
$\mathrm{Cr}$ & 23.84 & 6.63 & $99 \%$ \\
$\mathrm{Cu}$ & 19.78 & 6.63 & $99 \%$ \\
$\mathrm{Ir}$ & 23.94 & 6.63 & $99 \%$ \\
$\mathrm{Na}$ & 18.59 & 6.63 & $99 \%$ \\
$\mathrm{Ni}$ & 15.08 & 6.63 & $99 \%$ \\
$\mathrm{~S}$ & 11.26 & 3.84 & $95 \%$ \\
$\mathrm{Y}$ & 23.94 & 6.63 & $99 \%$ \\
$\mathrm{Zr}$ & 12.11 & 3.84 & $95 \%$ \\
\hline
\end{tabular}

$\mathrm{H}$ - value of the discrimination test approaching the values of the chi-square distribution;

$\mathrm{p}$ - probability of sources being different from one another, according to the chi-square distribution.

Seven elements were selected at $99 \%$ significance level and three when significance decreased to $95 \%$. Yet, Miguel et al. (2014) drew attention to unstable elements, e.g. $\mathrm{Na}$, which can be modified as their contents increase in suspended sediments, thereby compromising the analysis of each source contribution. The $\mathrm{Cr}, \mathrm{Cu}, \mathrm{Ir}$, and $\mathrm{Ni}$, which are classified as transition metals, showed discriminant capacity for sources and presented good conservation, being able to maintain their characteristics even after removed and transported to the river channel (Belmont et al., 2014).
Although indicated as a discriminant element, C could not be used to identify sediment sources because of the laboratory procedures used for mineralogical analysis. After drying, the samples are fixed on a stub (metal support) with a carbon tape. This way, SEM-EDS readings are influenced by the tape, as the percentage of carbon belonging to the sample and the tape could not be distinguished. Notwithstanding, in other studies, $\mathrm{C}$ has been still a potential tracer since other analyses have been used to characterize sediments, as in the study of Collins \& Walling (2002) who made direct measurements by pyrolysis, or that of Brosinsky et al. (2014) who used 
spectroscopy for characterizations. Despite this, the elements in Table 4 are distinct from each other in terms of chemical and environmental properties, so they represent a good set for identification of sediment sources.

\section{Sediment source identification}

In the analysis of the discriminant potential of elements, a set of variables was defined as capable of discriminating soil types. The model was applied for identification of the source of sediments of the pond bed and the Benguê reservoir.

To identify sediment sources, an optimum composition of elements ( $\mathrm{Ca}, \mathrm{Ir}, \mathrm{Na}, \mathrm{Ni}, \mathrm{S}, \mathrm{Y}$, and $\mathrm{Zr}$ ) was established, following a numerical model (Equation 3). Table 5a shows the relative contributions of each source to the silted material in the pond, as well as the measured and modeled concentrations of the elements in sediments.

Latosols (59\%) followed by Argisols (33\%) and Luvisols (8\%) contributed the most to sediment formation in the pond; the other soil types were not identified. The results indicate that sediments from soil types located near the pond (Figure 2) are being retained, while sediments from farther sources, such as dystrophic and eutrophic Neosols, were not identified. Fine sediments originating from areas far from the control section are not retained in the pond, which presents a high outflow rate and, therefore, low efficiency in retaining suspended sediments. For larger particles originated at distant areas, the connectivity loss due to the large number of dams upstream and low runoff coefficients in the region (Medeiros et al., 2014) prevent them from reaching the pond.

Likewise, the numerical model (Equation 3) was also used to determine the sources of silted sediments in the Benguê reservoir, after establishing an optimum composition of elements $(\mathrm{Ca}, \mathrm{Cr}, \mathrm{Cu}, \mathrm{S}, \mathrm{Ir}, \mathrm{Y}, \mathrm{Na}, \mathrm{Ni}$, and $\mathrm{Zr}$ ). Table $5 \mathrm{~b}$ presents each source relative contribution to the composition of sediments in the reservoir, as well as the measured and modeled concentrations of the elements in sediments.

The results of sediment sources identification for the Benguê reservoir indicate the following contributions for the different soil types: Argisols - 50\%, eutrophic Neosols - 17\%, dystrophic Neosols - 16\%, Planosols $14 \%$, Luvisols - 3\%, except for Latosols, which had no significant contribution.

The sources Argisols, eutrophic Neosols, dystrophic Neosols, Planosols, and Luvisols were the ones that contributed the most to silted sediment deposition in the Benguê reservoir. This might have occurred because Argisols are located in the lower portion of the catchment, nearest the reservoir. Despite the distance to the outlet, Neosols are shallow and present high potential to generate runoff, contributing significantly to sediment yield in the catchment. Planosols occupy a relevant proportion of the area, being also close to the outlet, as shown in Figure 2 . By contrast, Latosols, which had no contribution to sedimentation in the reservoir, are deep with a high infiltration capacity, not being able to generate significant runoff in the study region; thus, this soil type produces low hydrological connectivity, what decreases its transport capacity of eroded sediments.

As discussed by Medeiros et al. (2014), reservoir networks act as effective barriers against sediment transport in the region, especially coarser fractions. This feature produces different impacts on deposition in the pond and the Benguê reservoir. In the former, the coarser fraction originates mostly from nearby soils, while sediments from farther sources are partially retained in the upstream reservoirs. Additionally, when there is flow, most of the fine sediments reaching the pond are transferred downstream through a flooded spillway. Oppositely, most of the sediments reaching the Benguê reservoir are retained since its outflow occurs only once every eight years.

TABLE 5. Relative contribution of sources to silted sediments in the pond and reservoir:

a) Pond

\begin{tabular}{|c|c|c|c|c|c|c|c|c|c|c|c|c|c|c|}
\hline \multirow[t]{2}{*}{ Element } & \multicolumn{2}{|c|}{$\mathbf{C}_{\mathrm{i}}$} & \multicolumn{2}{|c|}{ Luvisols } & \multicolumn{2}{|c|}{ Latosols } & \multicolumn{2}{|c|}{$\begin{array}{l}\text { Neosols - } \\
\text { dystrophic }\end{array}$} & \multicolumn{2}{|c|}{$\begin{array}{l}\text { Neosols - } \\
\text { eutrophic }\end{array}$} & \multicolumn{2}{|c|}{ Planosols } & \multicolumn{2}{|c|}{ Argisols } \\
\hline & Meas. & Mod. & $\mathbf{C}_{s i}$ & $\mathbf{P}_{3}$ & $\mathrm{C}_{\mathrm{si}}$ & $\mathbf{P}_{3}$ & $\mathbf{C}_{s i}$ & $\mathbf{P}_{8}$ & $\mathbf{C}_{3 \mathrm{i}}$ & $\mathbf{P}_{8}$ & $\mathrm{C}_{\mathrm{si}}$ & $\mathbf{P}_{8}$ & $\mathbf{C}_{s i}$ & $\mathbf{P}_{s}$ \\
\hline $\mathrm{Ca}$ & 0.16 & 0.15 & 0.19 & \multirow{7}{*}{0.08} & 0.11 & \multirow{7}{*}{0.59} & 0.00 & \multirow{7}{*}{0.00} & 0.32 & \multirow{7}{*}{0.00} & 0.00 & \multirow{7}{*}{0.00} & 0.21 & \multirow{7}{*}{0.33} \\
\hline Ir & 1.45 & 0.69 & 0.59 & & 1.08 & & 0.00 & & 0.00 & & 0.00 & & 0.00 & \\
\hline $\mathrm{Na}$ & 0.02 & 0.03 & 0.31 & & 0.00 & & 0.08 & & 0.00 & & 0.09 & & 0.00 & \\
\hline $\mathrm{Ni}$ & 0.69 & 0.26 & 0.89 & & 0.32 & & 0.00 & & 0.00 & & 0.37 & & 0.00 & \\
\hline $\mathrm{S}$ & 1.23 & 0.67 & 0.38 & & 0.00 & & 0.63 & & 1.18 & & 0.00 & & 1.94 & \\
\hline $\mathrm{Y}$ & 0.93 & 0.03 & 0.35 & & 0.00 & & 0.00 & & 0.00 & & 0.00 & & 0.00 & \\
\hline $\mathrm{Zr}$ & 10.31 & 12.12 & 0.00 & & 11.26 & & 23.04 & & 16.04 & & 13.61 & & 16.80 & \\
\hline
\end{tabular}


b) Benguê reservoir

\begin{tabular}{|c|c|c|c|c|c|c|c|c|c|c|c|c|c|c|}
\hline \multirow[t]{2}{*}{ Element } & \multicolumn{2}{|c|}{$\mathrm{C}_{\mathrm{i}}$} & \multicolumn{2}{|c|}{ Luvisols } & \multicolumn{2}{|c|}{ Latosols } & \multicolumn{2}{|c|}{$\begin{array}{l}\text { Neosols - } \\
\text { dystrophic }\end{array}$} & \multicolumn{2}{|c|}{$\begin{array}{l}\text { Neosols - } \\
\text { eutrophic }\end{array}$} & \multicolumn{2}{|c|}{ Planosols } & \multicolumn{2}{|c|}{ Argisols } \\
\hline & Meas. & Mod. & $\mathbf{C}_{s i}$ & $\mathbf{P}_{s}$ & $\mathrm{C}_{\mathrm{si}}$ & $\mathbf{P}_{s}$ & $\mathrm{C}_{3 \mathrm{i}}$ & $\mathbf{P}_{3}$ & $\mathrm{C}_{3 \mathrm{i}}$ & $\mathbf{P}_{3}$ & $\mathrm{C}_{3 \mathrm{i}}$ & $\mathbf{P}_{8}$ & $\mathrm{C}_{3 \mathrm{i}}$ & $\mathbf{P}_{s}$ \\
\hline $\mathrm{Ca}$ & 0.09 & 0.14 & 0.19 & \multirow{9}{*}{0.03} & 0.11 & \multirow{9}{*}{0.00} & 0.00 & \multirow{9}{*}{0.16} & 0.16 & \multirow{9}{*}{0.17} & 0.00 & \multirow{9}{*}{0.14} & 0.21 & \multirow{9}{*}{0.50} \\
\hline $\mathrm{Cr}$ & 0.00 & 0.00 & 0.00 & & 1.00 & & 0.00 & & 0.00 & & 0.00 & & 0.00 & \\
\hline $\mathrm{Cu}$ & 1.99 & 0.09 & 0.00 & & 0.00 & & 0.00 & & 0.00 & & 0.70 & & 0.00 & \\
\hline $\mathrm{S}$ & 0.46 & 1.28 & 0.38 & & 0.00 & & 0.63 & & 1.18 & & 0.00 & & 1.94 & \\
\hline Ir & 0.00 & 0.02 & 0.59 & & 1.08 & & 0.00 & & 0.00 & & 0.00 & & 0.00 & \\
\hline $\mathrm{Y}$ & 0.00 & 0.01 & 0.35 & & 0.00 & & 0.00 & & 0.00 & & 0.00 & & 0.00 & \\
\hline $\mathrm{Ni}$ & 0.00 & 0.08 & 0.89 & & 0.32 & & 0.00 & & 0.00 & & 0.37 & & 0.00 & \\
\hline $\mathrm{Na}$ & 0.00 & 0.04 & 0.31 & & 0.00 & & 0.08 & & 0.00 & & 0.09 & & 0.00 & \\
\hline $\mathrm{Zr}$ & 5.52 & 16.73 & 0.00 & & 11.26 & & 23.04 & & 16.04 & & 13.61 & & 16.80 & \\
\hline
\end{tabular}

$\mathrm{C}_{\mathrm{i}}-$ concentration of tracer element $i$ in the sediment sample;

$\mathrm{P}$ - proportion of the source $s$ contribution to sediments;

$\mathrm{C}_{\mathrm{si}}-$ average concentration of tracer variable $i$ in source $s$.

The results of sediment sources found in this study are qualitatively similar to those obtained by Medeiros et al. (2010), who used the WASA-SED mathematical model, i.e. the main sediment sources identified in the present study coincided with the sites with the highest sediment contribution indicated by these authors.

\section{CONCLUSIONS}

Fingerprinting technique proved to be a suitable tool to identify sediment sources in the study region, based on natural tracing properties (physical and mineralogical) of sediments deposited in the pond and Benguê reservoir.

The soil types that mostly contributed to sediment formation in the catchment outlet were: Argisols (50\%), eutrophic and dystrophic Neosols (17 and 16\%, respectively), and Planosols (14\%); these soil classes cover $30.3 \%, 7.1 \%, 7.9 \%$, and $30.3 \%$ of the catchment area, respectively. But, Latosols, which are present in $29.5 \%$ of the area, had no contribution to sediments silted in the outlet.

The use of fingerprinting was effective to understand the transport of sediments in the studied catchment, particularly regarding the transference from the pond (by spilling when there is flow in the stream) towards the Benguê reservoir (where outflow occurs once every eight years, on average).

\section{REFERENCES}

Araújo JC de, Güntner A, Bronstert A (2006) Loss of reservoir volume by sediment deposition and its impact on water availability in semiarid Brazil. Hydrological Sciences Journal 51(1):157-170. DOI: https://doi.org/10.1623/hysj.51.1.157

Belmont P, Willenbring JK, Schottler SP, Marquard J, Kumarasamy K, Hemmis JM (2014) Toward generalizable sediment fingerprinting with tracers that are conservative and nonconservative over sediment routing timescales. Journal of Soils Sediments 14:1479-1492. DOI: https://doi.org/10.1007/s11368-014-0913-5

Bronstert A, Araújo JC de, Batalla R, Costa AC, Francke T, Förster S, Güntner A, Lopez-Tarazon JA, Mamede GL, Medeiros PHA, Müller EN, Vericat D (2014) Processbased modelling of erosion, sediment transport and reservoir siltation in mesoscale semi-arid catchments. Journal of Soils and Sediments 14: 2001-2018. DOI: https://doi.org/10.1007/s11368-014-0994-1
Brosinsky A, Forester S, Selg K, López-Tarazón JA, Piqué G, Bronster A (2014) Spectral fingerprinting: characterizing suspended sediment sources by the use of VNIR-SWIR spectral information. Journal of Soils and Sediment 14:1965-1981. DOI: https://doi.org/10.1007/s11368-014-0927-z

Collins AL, Walling DE, Leeks GJL (1997) Source type ascription for fluvial suspended sediment based on a quantitative composite fingerprinting technique. Catena 29:1-27. DOI: https://doi.org/10.1016/S03418162(96)00064-1

Collins AL, Walling DE (2002) Selecting fingerprinting properties for discriminating potential suspended source in river basin. Journal of Hydrology 261:218-244. DOI: https://doi.org/10.1016/S0022-1694(02)00011-2

Collins AL, Walling DE, King P (2010) Apportioning catchment-scale sediment sources using a modified composite fingerprinting technique incorporating property weightings and prior information. Geoderma 155:249-261. DOI: https://doi.org/10.1016/j.geoderma.2009.12.008

EMBRAPA (1997) National Soil Research Center. Manual of Soil Analysis Methods.

Figueiredo JV, Araújo JC de, Medeiros PHA, Costa AC (2016) Runoff initiation in a preserved semiarid Caatinga small watershed, Northeastern Brazil. Hydrological Processes 30:2390-2400. DOI:

https://doi.org/10.1002/hyp.10801

Medeiros PHA, Araújo JC de (2014) Temporal variability of rainfall in a semiarid environment in Brazil and its effect on sediment transport processes. Journal of Soils and Sediments 14:1216-1223. DOI:

https://doi.org/10.1007/s11368-013-0809-9

Medeiros PHA, Araújo JC de, Mamede GL, Creutzfeldt B, Güntner A, Bronstert A (2014) Connectivity of sediment transport in a semiarid environment: a synthesis for the Upper Jaguaribe Basin, Brazil. Journal of Soils and Sediments 14:1938-1948. DOI: https://doi.org/10.1007/s11368-014-0988-Z

Medeiros PHA, Guntner A, Francke T, Mamede G, Araújo JC de (2010) Modelling spatio-temporal patterns of sediment yield and connectivity in a semi-arid catchment with the WASA-SED model. Hydrological Sciences Journal 55:636-648. DOI: https://doi.org/10.1080/02626661003780409 
Minella JPG, Merten GH, Clarke RT (2009) Método

"fingerprinting" para a identificação de fontes de sedimentos em bacia hidrográfica rural. Revista Brasileira de Engenharia Agrícola e Ambiental 13:633-638. DOI: http://dx.doi.org/10.1590/S1415-43662009000500017

Miguel P, Dalmolin RSD, Pedron FA, Moura-Bueno JM, Tiecher T (2014) Identificação de fontes de produção de sedimentos em uma bacia hidrográfica de encosta. Revista Brasileira de Ciências do Solo 38:585-598. DOI: http://dx.doi.org/10.1590/S0100-06832014000200023

Poleto C, Merten GH, Minella JP (2009) The identification of sediment sources in a small urban watershed in southern Brazil: an application of sediment fingerprinting. Environmental Technology 30:1145-1153. DOI: https://doi.org/10.1080/09593330903112154

RadamBrasil (1981) Leaves SB 24/25 Jaguaribe/Natal; geology, geomorphology, pedology, vegetation and potential land use. Survey of Natural Resources, vol. 23. Ministry of Mines and Energy, Rio de Janeiro, Brazil.
Santos JCN, Andrade EM, Medeiros PHA, Guerreiro MJS, Palácio HAQ (2016) Effect of rainfall characteristics on runoff and water erosion for different land uses in a tropical semiarid region. Water Resources Management 31:173-185. DOI: https://doi.org/10.1007/s11269-016$1517-1$

Santos JCN, Andrade EM, Medeiros PHA, Guerreiro MJS, Palácio HAQ (2017) Land use impact on soil erosion at different scales in the Brazilian semi-arid. Revista Ciência Agronômica 48:251-260. DOI: http://dx.doi.org/10.5935/1806-6690.20170029

Walling DE, Woodward JC (1995) Tracing sources of suspended sediment in river basins: a case study of the River Culm, Devon, UK. Marine Freshwater Resources 46:327-336.

Walling DE, Collins AL (2000) Integrated assessment of catchment sediment budgets: a technical manual. Exeter: Department for International Development.

Walling DE (2013) The evolution of sediment source fingerprinting investigations in fluvial systems. Journal of Soil Sediments 13:1658-1675. DOI: https://doi.org/10.1007/s11368-013-0767-2 